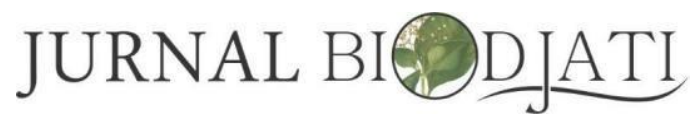

http://journal.uinsgd.ac.id/index.php/biodjati

\title{
ETNOEKOLOGI, BIODIVERSITAS PADI DAN MODERNISASI BUDIDAYA PADI: STUDI KASUS PADA MASYARAKAT BADUY DAN KAMPUNG NAGA
}

\author{
Johan Iskandar ${ }^{1}$, Budiawati Supangkat Iskandar ${ }^{2}$ \\ ${ }^{1}$ Prodi Biologi, FMIPA dan Sekolah Pascasarjana Ilmu Lingkungan, CESS (Center for Environ- \\ ment and Sustainability Science), UNPAD, ${ }^{2}$ Prodi Antropologi, FISIF UNPAD
}

\begin{tabular}{l} 
Diterima : 20 April 2018 \\
Disetujui : 22 Mei 2018 \\
Publish : 31 Mei 2018 \\
\hline J1. Raya Jatinangor Km. \\
21, Sumedang 45363 Jawa \\
Barat, Indonesia \\
e-mail \\
${ }^{1}$ johan.iskandar@unpad.ac.id, \\
${ }^{2}$ budiawati.supangkat@unpad.a \\
$\underline{\underline{c . i d}}$
\end{tabular}

e-ISSN : 2541-4208

p-ISSN : 2548-1606
Abstrak. Program Revolusi Hijau di Indonesia mulai digulirkan di akhir 1960-an. Program ini telah memberikan dampak positif dan negatif. Dampak positif di antaranya dapat meningkatkan poduktivitas padi sawah secara makro. Sementara itu, dampak ngatifnya diantara telah menyebabkan kepunahan anekaram varietas padi lokal secara masif. Oleh karena itu, kajian tentang kepunahan anekaragam padi lokal di berbagai kawasan perdesaan di Jawa Barat dan Banten sangat penting untuk diteliti. Tujuan penelitian ini yaitu mengkaji pengetahuan masyarakat perdesaan tentang ekologi, terutama kaitannya dengan pengeloaan keanekaragaman varietas padi lokal dan perubahannya dampak Revolusi Hijau, berlandaskan dari studi kasus pada masyarakat Baduy, Desa Kanekes, Kabupaten Lebak, Banten Selatan dan masyarakat Kampung Naga, Tasikmalaya, Jawa Barat. Penelitian ini menggunakan metoda kualitatif dengan menggunakan pendekatan etnoekologi, yaitu peneliti mempelajari pengetahuan penduduk perdesaan tentang berbagai aspek ekologi dalam kaitannya dengan pengeloaan padi lokal. Teknik pengumpulan data lapangan dilakukan dengan observasi dan wawancara mendalam terhadap informan yang kompeten yang dipilih secara' purposive'. Hasil penelitian menunjukkan bahwa sejatinya para petani 'huma' Baduy dan petani sawah Kampung Naga memiliki peran penting dalam mengkonservasi anekaragam varietas padi lokal secara in-situ. Namun, akibat program Revolusi Hijau, beberapa varietas padi lokal sawah penduduk Kampung Naga mengalami kepunahan. Sementara itu, kepunahan anekaragam varietas padi lokal di 'huma' Baduy tidak terdokumentasikan. Mengingat penduduk Baduy tidak menerima program Revolusi Hijau. Kepunahan keanekaragam varietas padi lokal dapat disebabkan oleh berbagai faktor, seperti kebijakan pemerintah, perubahan ekosistem, dan akibat perubahan sistem sosial ekonomi dan budaya masyarakat. Penelitian ini dapat memiliki kontribusi penting untuk ilmu pengetahuan dan kepentingan praktis. Berdasarkan kepentingan ilmu pengetahuan yaitu dapat bermanfaat untuk pengembangan ilmu pengetahuan, khususnya dalam bidang etnoekologi dan etnobotani. Sementara itu, untuk kepentingan praktis, diharapkan hasil penelitian ini dapat digunakan untuk dijadikan masukan bagi berbagai pihak terkait, guna upaya konservasi anekaragam padi di Indonesia. 


\section{JURNAL BIODJATI}

http://journal.uinsgd.ac.id/index.php/biodjati

Kata kunci: etnoekologi, etnobotani, keanekaragam varietas padi, Revolusi Hijau.

Absrtract. The Green Revolution program in Indonesia was firstly introduced in the end of 1960s. This program has some positive and negative effects. One of positive impacts of the Green Revolution was able to increase sawah rice productivity in macro level. While the negative impacts of this program, such as causing of gradual extinction of local rice varieties.Therefore, study on extinction of local rice varieties in some rural areas of West Java and Banten has been considered to be important. The aim of this study was to discuss local knowledge of rural people on ecology, particulary in relation to local management of rice biodiversity and its canged caused by the Green Revolution program, based on case study in the Baduy community, Kanekes village, Lebak district, South Banten and Naga people, Tasikmalaya, West Java. The method used in this study was qualitative which etnoecological approach was applied, namely researchers study on local knowledge of rural people on ecology, particularly in relation to management of local rice vities. Some techniques, including observation and deep interviews were undertaken with competent impormants that were purposivelly selected to collect the field data. Result of study showed that initially both the Baduy and Naga community had been an important role in conserving various local rice varieties insitu. However, due to introduction of the Green Revolution program, some local rice varieties of Naga community have disappeared. While extinct of local rice varieties has been not documented in Baduy community. Due to the Green Revolution was rejected by the Baduy. The extinction of local rice varieties is caused by many factors, including the government policy, ecosystem changes, and socio-economic and cultural community changes. This study can provided important contribution for scientific development and practical purpose. For the scientific development, this study can contribute for scientific development, particularly ethnoecology and ethnobotany. While in terms of practical purpose, hopefully this study can be used as policy inputs for stakeholders to conserve various local rice varieties in Indonesia.

Key words: ethnoecology, ethnobotany, rice biodiversity, Green Revolution.

\section{Cara Sitasi}

Iskandar, J. \& Iskandar, B. S. (2018). Etnoekologi, Biodiversitas Padi dan Modernisasi Budidaya Padi: Studi Kasus Pada Masyarakat Baduy dan Kampung Naga. Jurnal Biodjati, 3 (1), 47-62.

\section{PENDAHULUAN}

Berdasarkan sejarah ekologi atau sejarah lingkungan, di masa lalu sebelum program
Revolusi Hijau, Indonesia memiliki tak kurang dari 8.000 varietas padi (Bernsten et al., 1982 ; Fox 1991 ; Whitten et al., 1999). Berbagai faktor yang dapat menyebabkan In- 


\section{JURNAL BIDDJATI}

http://journal.uinsgd.ac.id/index.php/biodjati

donesia memiliki kenekaragam varietas padi antara lain, karena Indonesia memiliki ankaragam habitat tempat tumbuh padi di berbagai ekosistem lokal, dan pengaruh anekaragam budaya manusia yang membudidayakan tanaman padi (Beets, 1990 ; Brush, 1992 ; Sastrapradja \& Widjaja, 2010).

Sejatinya secara tradisional para petani di Indonesia mengelola tanaman padi dilandasi oleh pengetahuan ekologi tradisional (Traditional Ecological Knowledge=TEK), dengan lekat budaya, seperti kepercayaan atau kosmos petani (Mustapa, 1996 ; Berkes, 1999 ; Toledo, 2002). Pengetahuan tradisional ekologi disini dimaksudkan adalah sebagai 'sistem pengetahuan lokal yang unik menarik dihasilkan dari suatu budaya atau masyarakat, kontras dengan sistem ilmu pengetahuan internasional atau ilmu pengetahuan ilmiah Barat yang dihasilkan melalui jaringan global universitas-universitas dan lembaga-lembaga penelitian' (Warren et al., 1995 ; Ellen \& Harris 2000).

Penduduk Indonesia di berbagai kawasan biasa membudidayakan tanaman padi di berbagai habitat atau ekosistem lokal berdasarkan pengetahuan ekologi tradisional (TEK) yang mereka miliki hasil pewarisan secara turun temurun, serta hasil pengalaman pribadi interaksi timbal balik antara dirinya dengan ekosistem lokal secara berkelanjutan dengan lekat budaya. Imbasnya, menghasilkan anekaragam varietas padi di berbagai wilayah Indonesia. Berdasarkan studi etnobotani pada masyarakat Dayak Kenyah Umak Tukung di Long Sungai Barang, Apo Kayan, tercatat minimal 25 varietas padi yang biasa ditanam penduduk di sistem ladang (Wijaya \& Jessup 1986). Setyawati (1999) juga mencatat 38 varietas padi yang biasa dikelola oleh Orang Kenyah Leppo'ke di Apoping, Kalimantan Timur. Peneliti lainnya, Damus (1992, 1993) mendokumentasikan 58 varietas padi lokal di dua desa Pujungan, Kalimantan Timur. Sementara itu, Dove (1988) mengemukakan bahwa 44 jenis varietas padi ladang yang biasa dibudidayakan oleh penduduk Suku Kantu Kalimanatan Barat. Demikian pula hasil studi etnobotani tanaman padi di Jawa Barat dan Banten, pada masyarakat Baduy Banten telah mencatat 89 varietas padi ladang yang dibudidayakan penduduk Baduy secara lekat budaya (Iskandar \& Ellen 1999). Selain itu, pada masyarakat Kasepuhan, Cisolok, Sukumi Selatan, tercatat 35 varietas padi ladang yang dikelola oleh penduduk Kasepuhan (Budi, 1997 ; Soemarwoto, 2007). Sementara itu, varietas padi lokal yang biasa ditanam di sawah, masyarakat Rancakalong, Sumedang biasa dibudidayakan 22 varietas padi lokal oleh para petani sawah (Warsiti, 2009),dan pada masyarakat Kampung Naga dapat dicatat 15 varietas padi lokal (Permana et al., 2017). Sedangkan pada masyarakat Kasepuhan, Sukabumi Selatan telah tercatat 112 varietas padi lokal yang ditanam penduduk pada sistem sawah (Budi, 1997 ; Soemarwoto, 2007).

Dalam rangka meningkatkan produksi padi sawah, pemerintah Indonesia memperkenalkan program Revolusi Hijau pada akhir tahun 1960-an. Program tersebut antara lain memperkenalkan beberapa varietas padi unggul baru, seperti IR5 dan IR8. Program Revolusi Hijau selain memberikan keuntungan, seperti meningkatkan produksi padi sawah secara makro. Namun program ini juga menyebabkan berbagai kerugian, seperti mengakibatkan kepunahan anekaragam varietas padi lokal di Indonesia (Fox, 1991 ; Shiva, 1991 \& 1993 ; Parikesit et al., 1997 ; Iskandar, 2001 ; Hardiyoko \& Saryoto, 2005 ; Soemarwoto, 2007 ; Warsiti, 2009 ; Permana, 2017). Punahnya anekaragam varietas padi lokal tersebut telah menimbulkan kerugian yang luar biasa. Seperti hilangnya bahan dasar untuk pemuliaan tanaman padi guna 


\section{JURNAL BIODJATI}

http://journal.uinsgd.ac.id/index.php/biodjati

menghasilkan anekaragam varietas padi guna berbagai kebutuhan dalam program pembangunan pertanian di masa depan. Selain itu, hilangnya anekaragam varietas padi lokal juga telah menyebabkan menurunkan daya lenting petani untuk bercocok tanam padi dengan mengadaptasikan pada berbagai kondisi dan perubahan lingkungan yang berubah-ubah, seperti menghadapi perubahan iklim global serta kerentanan ketahanan pangan (Hardiyoko \& Saryoto, 2005). Tidak hanya itu, homogenisasi atau penyeragaman penanaman varietas padi unggul, telah menyebabkan tanaman padi sawah rentan terhadap serangan hama dan penyakit, seperti wereng coklat, tungro dan lainnya (Fox, 1991 ; Jhamtani, 2008 ; Hardiyoko \& Saryoto, 2005; Sastrapradja \& Widjaja, 2010).

Berbagai studi etnobotani tentang pengetahuan penduduk mengenai anekaragam varietas padi dan pengelolaan pada sistem ladang dan sawah di Indonesia telah dilakukan beberapa peneliti (Setyawati, 1999 ; Iskandar \& Ellen, 1999 ; Purnama, 2017). Meski demikian, pengkajian perubahan varietas padi imbas dari modernisasi budidaya tanaman padi dengan belandaskan pendekatan etnoekologi dan etnobotani masih kurang. Pengkajian etnoekologi dan etnobotani padi sangat penting guna memahami petani dalam budidaya dan konservasi padi dibalut budaya lokal, dapat digunakan untuk pengembangan ilmu pengetahuan dan kepentingan praktis seperti konservasi padi lokal di Indonesia.

Artikel ini membahas tentang etnoekologi, biodiversitas padi, dan modenisasi budidaya padi berdasarkan studi kasus pada masyarakat Baduy, Desa Kanekes, Lebak, Banten Selatan dan masyarakat Kampung Naga, Tasikmalaya, Jawa Barat (Gambar 1).

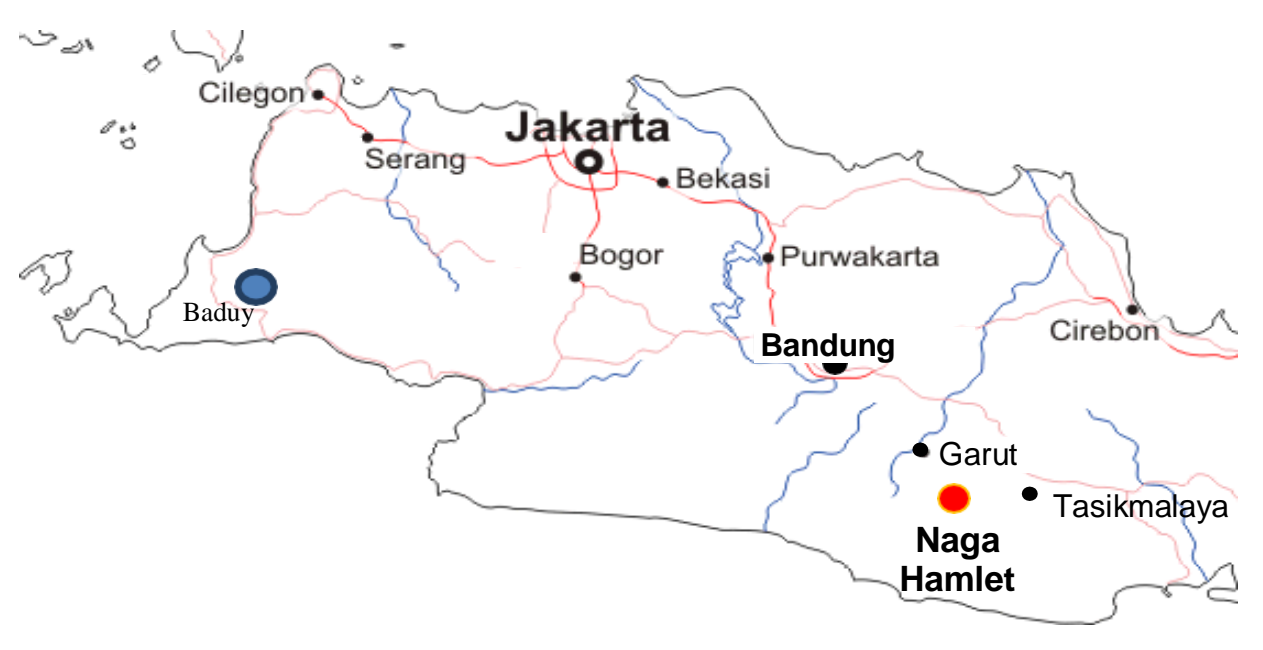

Gambar 1. Lokasi penelitian di kawasan Baduy, Banten Selatan dan Kampung Naga, Tasikmalaya

\section{BAHAN DAN METODE}

Penelitian ini menggunakan metoda kualitatif dengan pendekatan etnoekologi
(Iskandar, 2012 ; Alburquerque et al., 2014). Pengumpulan data lapangan dilakukan dengan cara observasi dan wawancara semi-struktur dengan informan kompeten, seperti para 


\section{JURNAL BIODJATI}

http://journal.uinsgd.ac.id/index.php/biodjati

pimpinan informal, kepala dusun, kepala desa dan para stafnya, petani laki-laki dan para petani perempuan. Analisis data mencakup cross-checking data yang diperoleh dari berbagai teknik pengumpulan data. Semua data tersebut kemudian dirangkum dan dintisarikan, serta dinarasikan secara deskriptif analisis (Newing et al., 2011).

\section{Etnoekologi Penduduk Baduy dan Penduduk Naga}

Penduduk Baduy memiliki pengetahuan mendalam tentang anekaragam lanskap di daerahnya. Berdasarkan masyarakat Baduy, anekaragam lanskap didaerahnya dapat dibedakan menjadi 2 kategori utama yaitu lanskap alami (natural landscape) dan lanskap binaan (man-made landscape) (Gambar 2).

\section{HASIL DAN PEMBAHASAN}

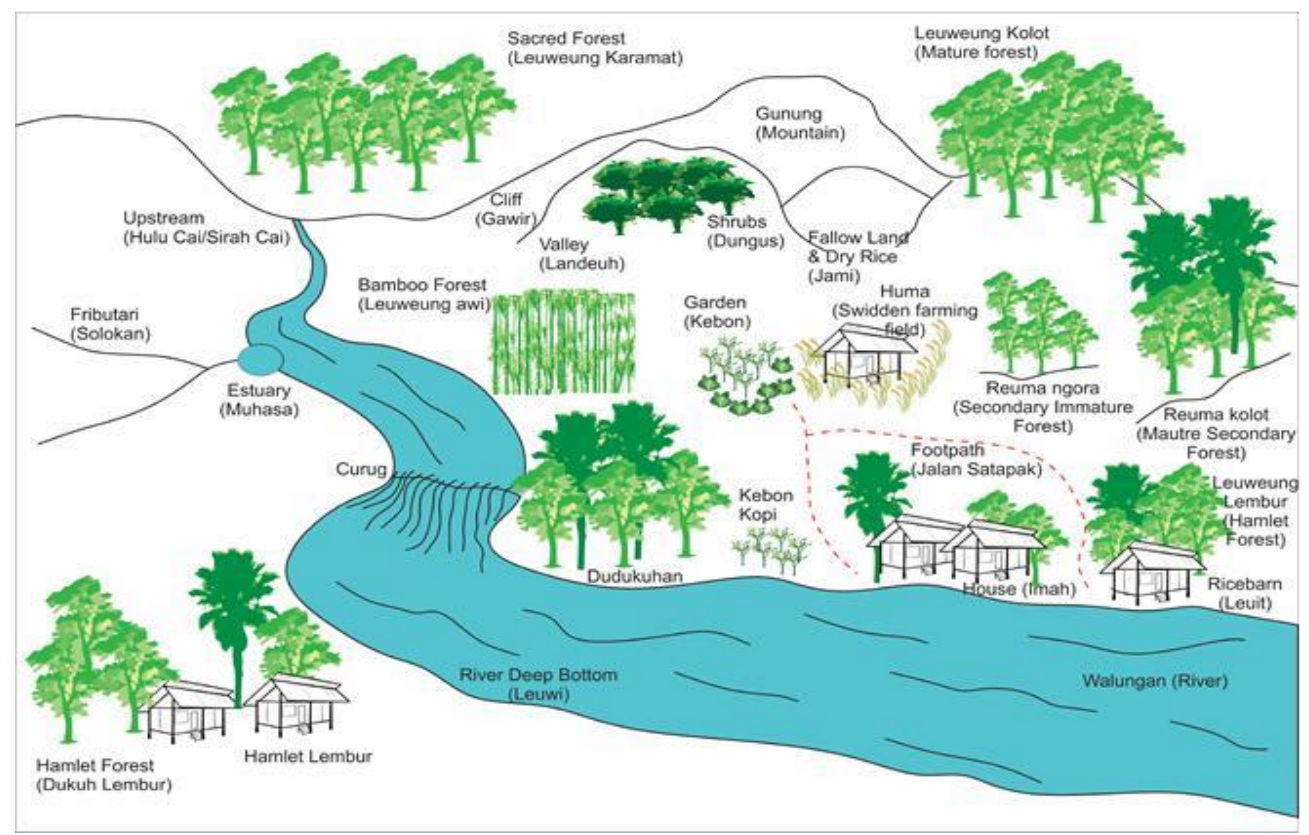

Gambar 2. Macam-macam landskap di kawasan Baduy, Banten Selatan ( Iskandar \& Iskandar, 2017a)

Umumnya, tiap gunung atau bukit Baduy dapat dibagi menjadi 3 zonasi yaitu zona satu kawasan lembah gunung atau bukit, zona dua kawasan di atas zona satu (di atas lembah bukit) dan zona ketiga, kawasan puncakpuncak bukit. Zona satu, kawasan lembah gunung atau bukit biasa diperuntukan bagi kawasan permukiman (lembur) dan lumbung padi (leuit), serta hutan kampung (leuweung lembur). Pada zona satu ini juga biasanya terdapat sumber air dan pancuran (tampian) untuk mandi dan mencuci, ataupun terdapat sungai (wahangan) dengan sungai utamanya S. Ciujung. Zona kedua, lokasinya di atas kawasan permukiman, berupa kawasan untuk berladang (ngahuma) dan kawasan hutan bekas ladang yang sedang diberakan, berupa hutan sekunder muda (reuma ngora) dan hutan sekunder tua (reuma kolot). Pada zona dua ini, terdapat ladang (huma), khususnya pada musim beraladang serta hutan sekunder (reuma) dengan berbagai tingkatan umur. Zona tiga lokasinya di atas kawasan zona dua, berupa kawasan puncak-puncak bukit, dengan 


\section{JURNAL BIODJATI}

http://journal.uinsgd.ac.id/index.php/biodjati

ditumbuhi oleh hutan tua (leweung kolot) (Iskandar, 2017).

Sama halnya dengan Orang Baduy, masyarakat Kampung Naga, Tasikmalaya juga memiliki pengetahuan tentang lanskap di daerahnya dan dikelola dengan sistem zonasi berdasarkan pengetahuan ekologi lokal secara lekat budaya. Berbagai lanskap di Kampung Naga antara lain hutan (leuweung), kebun (kebon) ataupun kebun campuran (kebon tatangkalan), sawah, sungai (walungan), dan permukiman atau kampung (lembur) (Gambar 3).

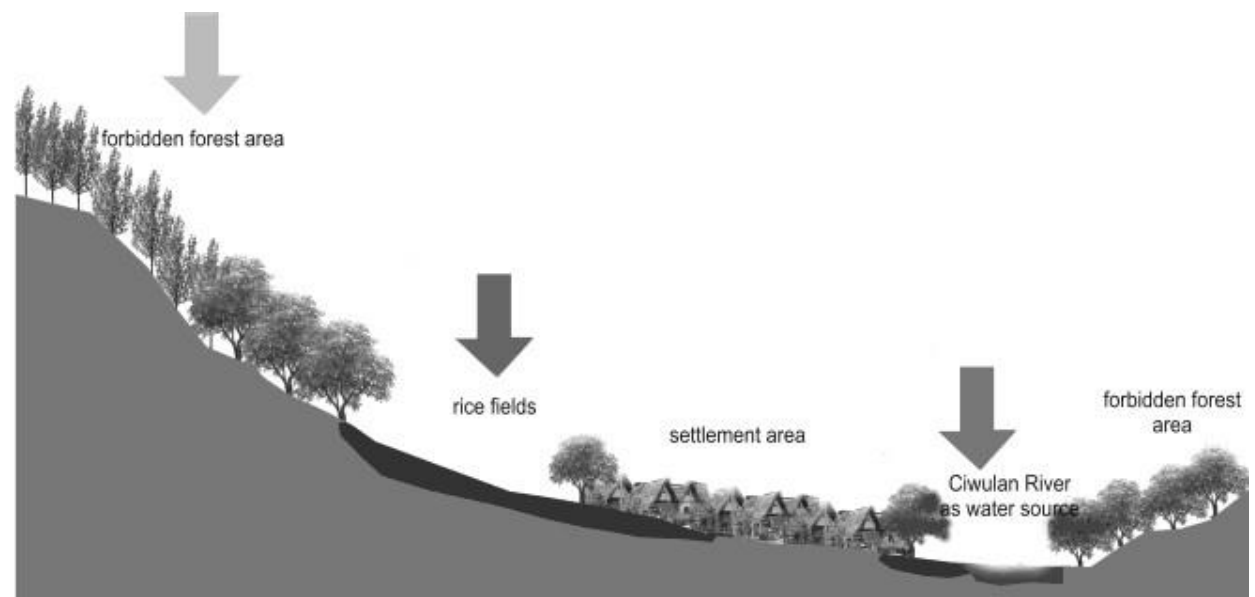

Gambar 3. Macam-macam lanskap di Kampung Naga, Tasikmalaya ( Sudarwani, 2016)

Berdasakan tradisi penduduk Kampung Naga, menurut kesakralannya kawasan mereka dapat dibedakan menjadi 3 zonasi yaitu zona kawasan suci, zona kawasan bersih, dan zona kawasan kotor (Suganda, 2006; Iskandar 2017). Kawasan suci di antaranya berupa hutan kecil yang ditumbuhi pohon-pohon tua yang biasa disebut 'leuweung larangan' (hutan pantangan), dalam kawasan hutan tesebut terdapat pemakaman para leluhur mereka. Pada kawasan hutan suci ditumbuhi jenis-jenis pohon hutan yang umurnya sudah ratusan tahun. Menurut peduduk Kampung Naga, 'leuweung larangan' senantiasa dijaga kelestariannya dan kesuciannya, sehingga kawasan tersebut tidak boleh dikunjungi sembarangan orang.

Zona kawasan bersih, berupa kawasan kampung (lembur) tempat permukiman rumahrumah (imah) warga Naga, serta bangunan lainnya seperti balai pertemuan (bale patemon), masjid (masjid) dan lumbung padi (leuit). Sementara itu zona kawasan kotor, di luar kawasan bersih yang letaknya bersebelahan dengan Sungai Ciwulan. Pada kawasan ini, terdapat beberapa bangunan bentuk sederhana seperti pancuran air untuk mandi dan mencuci, bangunan untuk menumbuk padi (saung lisung), kandang ternak dan kolam ikan (empang). Pada kawasan ini, terdapat daur materi dan energi secara efisien seperti kotoran ternak untuk pupuk tanaman, sisa numbuk padi (huut) dan sisa makanan dari mencuci pring di pancuran menjadi pakan ikan di kolam (Iskandar, 2017).

\section{Pengetahuan Tentang Varietas Padi}

Penduduk Baduy dan penduduk Naga, seperti halnya masyarakat Sunda umumnya memiliki pengetahuan taksonomi (folk taxonomy) tumbuhan dalam 4 tingkatan dari tingkat atas ke bawah (Iskandar, 2012), yaitu 


\section{JURNAL BIDDJATI}

http://journal.uinsgd.ac.id/index.php/biodjati

level 0 (uniqe beginner) dikenal dengan istilah lokal tutuwuhan (tumbuhan) dan pepelakan (tanaman). Level 1 (life forms) dikenal seperti istilah kakayon (pepohonan kayu) dan jukutjukutan (rumput-rumputan). Pada tingkat 3 (specific/species) dikenal istilah lokal pare (padi). Bahkan pada level 4 (varietal/subspecies), pengetahuan penduduk Baduy dan Naga sangat kaya dan mendalam (Berlin et al., 1973 ; Brown 2000). Misalnya, di masyarakat Baduy mengenal macam-macam varietas padi lokal (landraces) atau disebut istilah lokalnya huasan pare atau di masyarakat Naga disebut jinis pare.

Spesies tanaman padi (Oryza sativa L.) menurut penduduk Baduy ataupun penduduk Naga diberi nama pare dan gabahnya yang telah ditumbuk disebut beas (beras), serta beras yang telah ditanak dinamakan sangu ataupun kejo (nasi). Total varietas padi lokal sistem ladang (huma) di masyarakat Baduy Luar dan masyarakat Baduy Dalam tercatat 89 varietas (huasan). Berbagai huasan pare tersebut oleh penduduk Baduy (pandangan emik), diklasifikasikan (folk classification) berdasarkan pada bentuk morfologi gabah berbulu (huasan pare bulu) dan tidak berbulu (huasan pare leger), bentuk gabah, warna beras, warna jerami, citarasa kuliner, kesakralan dan umur panen padi (Tabel 1).

Sementara itu, total varietas padi lokal (jinis pare) sawah di masyarakat Kampung Naga tercatat agak sedikit dengan total 15 jinis (landraces). Berbagai jinis pare tersebut oleh penduduk Kampung Naga diklasifikasikan berdasarkan morfologi gabah, warna biji gabah, warna beras, cita rasa (kuliner), kesesuaian tempat tumbuh dan umur panen (Tabel 2). Berdasarkan hasil kajian tentang pengetahun penduduk Baduy dan Penduduk Naga mengenai anekaragam varietas padi menunjukkan bahwa penduduk lokal, seperti hal penduduk lokal di berbagai kawasan Indonesia secara lintas budaya mempunyai pengetahuan ekologi yang mendalam tentang anekaragam varietas padi (Damus, 1992 \& 1993 ; Setyawati, 1999 ; Warsiti, 2000).

Tabel 1. Klasifikasi padi lokal (Oryza sativa L) menurut masyarakat Baduy, Lebak, Banten Selatan.

\begin{tabular}{|c|c|c|c|}
\hline No & Klasifikasi masyarakat & Sub-klasifikasi & $\begin{array}{l}\text { Jumlah varietas } \\
\text { (landraces) }\end{array}$ \\
\hline \multirow[t]{2}{*}{1} & Morfologi biji gabah berbulu dan tidak & Berbulu (pare bulu) & 39 \\
\hline & berbulu & Tidak berbulu (pare leger) & 60 \\
\hline \multirow[t]{2}{*}{2} & Bentuk gabah & Bentuk normal (biasa) & 68 \\
\hline & & Bentuk tipis (ipis) & 1 \\
\hline \multirow[t]{3}{*}{3} & Warna beras (warna beas) & Beras putih (beas bodas) & 68 \\
\hline & & Beras merah (beas beureum) & 20 \\
\hline & & Beras hitam (beas hideung) & 1 \\
\hline \multirow[t]{2}{*}{4} & Warna jerami padi (jarami pare) & Normal (biasa) & 88 \\
\hline & & Warna hitam (jarami hideung) & 1 \\
\hline \multirow[t]{2}{*}{5} & Citarasa kuliner & Padi ketan (pare ketan) & 16 \\
\hline & & Padi non-ketan (pare lain ketan) & 73 \\
\hline \multirow[t]{2}{*}{6} & Keskaralan & Padi sakral (pare sakral) & 3 \\
\hline & & Padi non-sakral (pare biasa) & 86 \\
\hline \multirow[t]{2}{*}{7} & Umur panen & Umur singkat/hawara (4-5 bulan) & 2 \\
\hline & & Umur biasa (5-6 bulan) & 87 \\
\hline
\end{tabular}

Diadapasi dari Iskandar dan Ellen (1999). 


\section{JURNAL BIDDJATI}

http://journal.uinsgd.ac.id/index.php/biodjati

Tabel 2. Klasifikasi padi lokal (Oryza sativa L.) menurut masyarakat Kampung Naga, Tasikmalaya, Jawa Barat

\begin{tabular}{|c|c|c|c|}
\hline No & Klasifikasi masyarakat & Sub-klasifikasi & $\begin{array}{l}\text { Jumlah varietas } \\
\text { (landraces) }\end{array}$ \\
\hline \multirow[t]{2}{*}{1} & \multirow{2}{*}{ Morfologi gabah } & Gabah berbulu(buntutan) & 11 \\
\hline & & Gabah tidak berbulu (henteu buntutan) & 4 \\
\hline \multirow[t]{4}{*}{2} & \multirow[t]{4}{*}{ Warna biji gabah } & Putih ( bodas) & 1 \\
\hline & & Merah (beureum) & 1 \\
\hline & & Hitam hideung) & 2 \\
\hline & & Kuning (Koneng) & 11 \\
\hline \multirow[t]{3}{*}{3} & \multirow[t]{3}{*}{ Warna beras } & Beras putih (beas bodas) & 13 \\
\hline & & Beras merah (beas beureum) & 1 \\
\hline & & Beras hitam (beas hideung) & 1 \\
\hline \multirow[t]{4}{*}{4} & \multirow[t]{4}{*}{ Kuliner } & Liket (pulen, enak) & 4 \\
\hline & & Biasa atau tidak liket (bear) & 11 \\
\hline & & Pare ketan & 2 \\
\hline & & Pare biasa (lain ketan) & 13 \\
\hline \multirow[t]{2}{*}{5} & \multirow[t]{2}{*}{ Kesesuaian tempat tumbuh } & $\begin{array}{l}\text { Subur berair (sawah ledok), kering tidak subur } \\
\text { (sawah anggar) sawah datar, berair dan banyak } \\
\text { penyunaran matahari (sawah negrak), sawah } \\
\text { baru dan kurang subur (sawah bebedahan) }\end{array}$ & 13 \\
\hline & & $\begin{array}{l}\text { Sawah ternaungi/ kurang mendapat penyinaran } \\
\text { matahari (sawah hieum) }\end{array}$ & 2 \\
\hline \multirow[t]{2}{*}{6} & \multirow[t]{2}{*}{ Umur panen } & Pare unggul, pare segon (3-4 bulan)*) & 3 \\
\hline & & Pare lokal/Pare ageung ( $5-6$ bulan) & 15 \\
\hline
\end{tabular}

*) Pare unggul (segon) ada 3 varietas yang umum ditanam penduduk, seperti IR64, Ciherang, dan Sarinah. Diadaptasi dari Pernana (2017).

Berbagai keanekaragam varietas padi tidak berbulu yang dikenal masyarakat Baduy disebut pare leger atau oleh masyarakat Kampung Naga pare henteu buntutan atau disebut pula pare gundil secara biologi merupakan subspecies dari Oryza sativa subsp javanica atau dikenal padi bulu atau disebut oleh penduduk Naga disebut pare buntutan atau oleh para petani Indramayu disebut pare bersongot (Fox, 1991 ; 1993 ; 1997 ; Winarto, 2011). Varietas padi lainnya biasa disebut pare cere merupakan sub-species dari Oryza sativa subsp indica. Menurut Fox (1991), pare bulu dan pare gundil (O. sativa javanica) masa panen lama, daun lebar, malai panjang, gabah besar kuat, kurang sensitif terhadap pencahayaan matahari dan menyukai tumbuh pada tanah vulkanik. Pare bulu juga lebih resisten terhadap serangan hama seperti burung dan babi liar (Burkill, 1935).
Sementara itu, pare cere (O.sativa indica) daun agak kecil, malai pendek, biji gabah ramping, sensitif terhadap sinar matahari, dan tumbuh pada tanah selain formasi vulkanik. Berdasarkan hasil penelitian Balai Penelitian Tanaman pada tahun 1977 mencatat 8.277 varietas padi di Indonesia, terdiri dari 5.275 tipe indica dan 3.002 tipe japonica (Soemartono, 2005). Varietas japonica memiliki karakteristik malai besar, daun besar, sistem perakaran kuat, batang tebal, dan telah digunakan dalam program penenelitian. Berdasarkan sejarah ekologi, berbagai kultivar indica ditanam di China bagian selatan, Asia Tenggara, dan Asia Selatan, sedangkan berbagai kultivar japonica ditanam terutama di Asia Timur (Widjaja et al., 2014).

Sementara itu, menrut (Fox, 1991 ; 1993) berdasarkan hasil penelusuran geneologi benih unggul yang direkayasa, seperti diawali 


\section{JURNAL BIDDJATI}

http://journal.uinsgd.ac.id/index.php/biodjati

PB8 dan PB5 memiliki bahan tetua Peta, hasil persilangan benih induk dari China dan benih jantan Latisail (dari Bengal atau India). Benihbenih unggul merupakan turunan dari varietas padi yang dikategorikan sebagai indica. Munculnya ciri-ciri malai berbulu itu kemungkinan berasal dari gen jenis padi berbulu (awned), turunan dari padi javanica.

\section{Budidaya Padi di Baduy dan Kampung Naga}

Penduduk Baduy membudidayakan padi pada sistem ladang berdasarkan pengetahuan ekologi lokal dan kepercayaan. Berdasarkan pengetahuan ekologi lokal masyarakat Baduy, waktu musim persiapan lahan dan tanam padi senantiasa menggunakan pedoman pranata mangsa atau pananggalan Orang Baduy. Guna menentukan awal tahun baru (tunggul tahun) dan waktu-waktu kesesuian tiap tahapantahapan budididaya padi diantaranya menggunakan indikator posisi rasi bintang kidang atau bentang kidang (the belt of orion). Secara tradisi, Orang Baduy juga percaya bahwa padi memiliki dewi padi yang disebut Nyi Pohaci (Dewi Sri di masyarakat Jawa). Oleh karena itu, sebagai rasa hormat pada Dewi Padi, maka setiap tahapan pengerjaan tanam padi senantiasa disertai dengan upacara dan waktu pengerjaanya tiap tahunnya tetap menggunakan pedoman pranata mangsa (pananggalan Baduy) (Iskandar, 1998 ; Iskandar \& Iskandar, 2017b).

Berdasarkan pananggalan Orang Baduy, tahun baru Orang Baduy pada bulan Sapar (April-Mei). Pada saat itu ladang serang (huma serang), huma sakral Baduy di Baduy Dalam, usai panen padi dan mulai menyiapkan lagi ladang tahun berikutnya seperti menebangi semak-semak belukar (nyacar), disertai upacara narawas (Iskandar \& Iskandar 2017c).. Pada bulan yang sama dilakukan upacara seba, menyampaikan persembahan hasil pertanian ke Rangkasbitung dan Serang (Gambar 4).

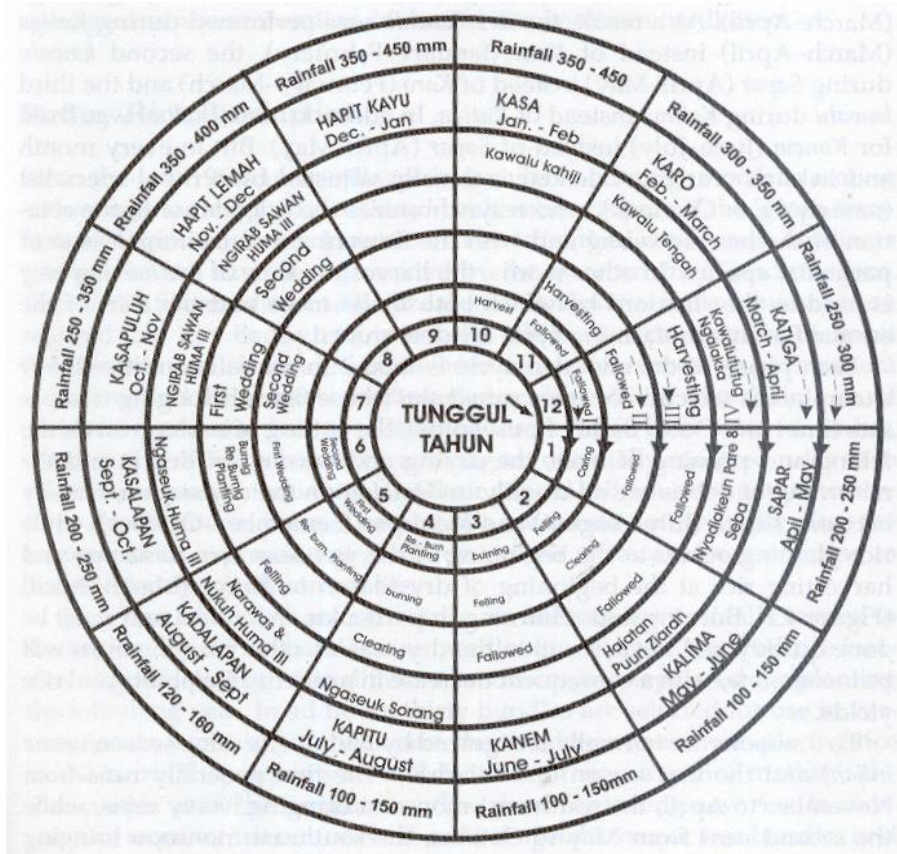

Gambar 4. Kalender tani Orang Baduy Banten Selatan (Iskandar 1998,2007) 


\section{JURNAL BIDDJATI}

http://journal.uinsgd.ac.id/index.php/biodjati

Pada masyarakat Kampung Naga seperti halnya masyrakat Baduy, dalam mengelola tanam padi di sawah menggunakan pedoman kalender tani atau pranata mangsa Orang Naga. Berdasarkan pranata mangsa tersebut, sebelum Revolusi Hijau sekitar tahun 1980-an masyarakat Kampung Naga hanya menanam padi lokal atau padi besar (pare ageung) dengan ditanam pada sekitar bulan Maret April (Mangsa Kasadasa) dan bulan September - Oktober (Mangsa Kapat/Kalima) (Gambar 5). Namun, sesudah penduduk Kampung Naga mengadopsi program Revolui Hijau, pada tahun 1984 padi yang ditanam tidak hanya satu tipe, berupa padi lokal (pare ageung) melainkan jadi 2 tipe yaitu padi lokal (pare ageung) dan padi unggul (padi modern). Oleh karena itu, mereka mengintegrasikan (hybrid) pola tanam padi unggul dengan pola tanam padi lokal (pare ageung). Pada musim tanam padi dengan varietas padi lokal biasa disebut pola musim tanam padi 'tahun besar'(taun ageung) dan pola tanam padi, varitas padi unggul disebut 'tahun kecil'(tahun alit). Penggunaan istilah 'tahun besar' dan 'tahun kecil' bukan merujuk pada pola penanaman padi di musim hujan (musim rendeng) disebut nyawah besar atau nyawah gede, serta tanam padi di musim kemarau (morekat, nyawah leutik, malik jarami) seperti umumnya di Tatar Sunda (Igarashi, 1985 ; Darpan, 2013). Namun varietas padi yang ditanam pada tahun besar (tahun ageung) adalah varietas padi yang ditanam padi lokal (pare ageung) dilakukan pada bulan Juni, Juli, Agustus, September, dan Nopember. Sedangkan pada tahun kecil (tahun alit) varietas padi yang ditanam adalah padi unggul (pare pendek), yang dilakukan pada bulan Januari, Februari, dan Maret. Sementara itu, waktu sisanya, bulan April, Mei, dan Desember merupakan masa lahan sawah diistirahatkan atau diberakan (Permana et al., 2017) (Gambar 5)..

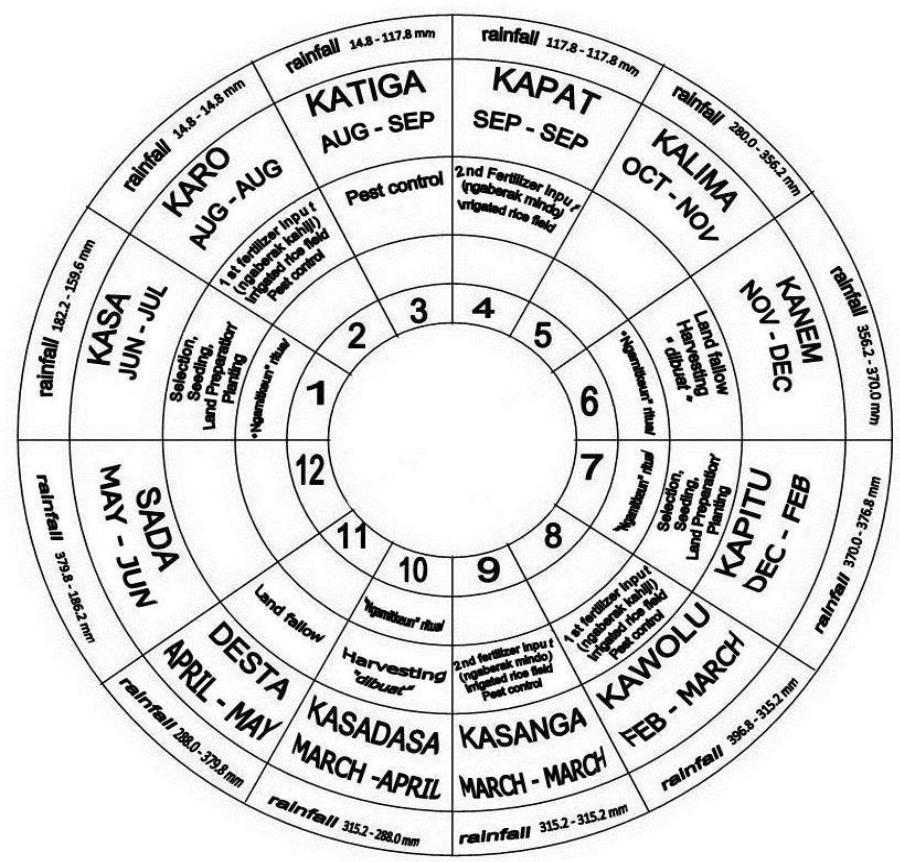

Gambar 5. Pranata mangsa masyarakat Kampung Naga, Tasikmalaya (Permana et al 2017). 


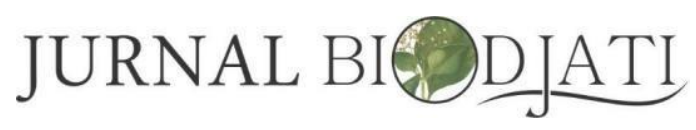

http://journal.uinsgd.ac.id/index.php/biodjati

\section{Dampak Modernisasi Budidaya Padi}

Dilihat dari sejarah ekologi, semenjak era kolonial Belanda, sistem ladang dilarang pihak pemerintah karena dianggap merusakan lingkungan, sebaliknya sistem sawah dipersepsikan tidak merusak lingkungan, dan terus dikembangkan (Kools, 1935). Bahkan pasca Kolonial sistem sawah terus mendapat perhatian dan diberi berbagai insentif dalam berbagai program pemerintah. Pada akhir 1960-an, pemerintah Indonesia memperkenalkan pogram Revolusi Hijau. Program tersebut utamanya usaha tani sawah diharuskan petani menggunakan varietas padi unggul baru, penggunaan pupuk anorganik, penggunaan pestisida sintesis, pembangunan dan perbaikan sistem irigasi, serta perbaikan metoda usaha tanam padi sawah (Iskandar 2001; Iskandar dan Iskandar 2011). Pada awal program Revolusi Hijau, diperkenalkan varietas padi unggul baru, seperti IR5 dari IR8 atau lebih dikenal dengan sebutan PB5 dan
PB8 diimpor dari IRRI (The International Rice Research), Philippines (Palmer, 1977; Soemardjan \& Breazale 1993 ; Iskandar, 2001 ; Sasatrapradja \& Widjaja, 2010). Program Revolusi Hijau telah berhasil meningkatkan produktivitas padi sawah secara bruto dan makro.Namun, demikian imbas dari program tersebut telah menyebabkan homogenisisasi penanaman varietas padi dengan didominasi oleh varietas padi unggul baru. Dampak negatifnya, telah menyebabkan kepunahan varietas padi lokal secara drastis di berbagai kawasan Indonesia. Misalnya, pada tahun 1986 sekitar $75 \%$ lahan sawah di Indonesia telah ditanami dengan varietas padi hibrida, dan lebih separuhnya hanya ditanami 2 varietas yakni Cisadane dan PB36 atau IR 36. Konsekuensinya, tidak kurang dari 1.500 varietas padi lokal menjadi langka bahkan banyak pula yang punah (Hardiyoko \& Saryoto 2005).

Tabel 3. Jumlah varietas padi lokal yang punah pasca Revolusi Hijau di Jawa Barat

\begin{tabular}{|c|c|c|c|c|}
\hline \multirow[t]{2}{*}{ No } & \multirow[t]{2}{*}{ Loasi dan sistem farming } & \multicolumn{2}{|c|}{ Jumlah varietas padi lokal } & \multirow[t]{2}{*}{ Sumber } \\
\hline & & $\begin{array}{l}\text { Sebelum Revolusi } \\
\text { Hijau }\end{array}$ & $\begin{array}{c}\text { Setelah Revolusi } \\
\text { hHijau }\end{array}$ & \\
\hline 1 & $\begin{array}{l}\text { Majalaya, Bandung, Jawa Barat } \\
\text { (sawah) }\end{array}$ & 88 & Less than 10 & $\begin{array}{l}\text { Parikesit et al. } \\
\text { (1997) }\end{array}$ \\
\hline 2 & $\begin{array}{l}\text { Rancakalong, Sumedang, Jawa } \\
\text { Barat (sawah) }\end{array}$ & 60 & 20 & Warsiti (2009) \\
\hline 3 & $\begin{array}{l}\text { Kampung Naga, Tasikmalaya, } \\
\text { Jawa Barat (sawah) }\end{array}$ & 24 & 15 & $\begin{array}{l}\text { Permana et al. } \\
\text { (2017) }\end{array}$ \\
\hline 4 & $\begin{array}{l}\text { Kasepuhan, Gunung Halimun, } \\
\text { Cisolok, Sukabumi, Jawa Barat } \\
\text { (huma dan sawah) }\end{array}$ & 146 & 78 & $\begin{array}{c}\text { Soemarwoto } \\
(2007)\end{array}$ \\
\hline 5 & Baduy, Banten Selatan (huma) & $?$ & 89 & $\begin{array}{l}\text { Iskandar \& } \\
\text { Ellen (1999) }\end{array}$ \\
\hline
\end{tabular}

Secara tradisi, masyarat Baduy membudidayakan padi ladang berdasarkan pengetahuan ekologi lokal secara lekat habitat dan lekat budaya. Menurut tradisi Baduy, padi ladang (pare huma) pantang atau tabu (teu wasa) diperdagangkan, dan biasa disimpan di lumbung-lumbung padi (leuit) hingga 50 tahun atau lebih (Iskandar, 1998 \& 2007; Iskandar \& Iskandar 2017b; Iskandar et al., 2018). Padi ladang utamanya hanya dimanfaatkan untuk kebutuhan berbagai upacara di ladang ataupun dikonsumsi sehari-hari, terutama kalau mereka tidak punya uang untuk membeli beras sawah 


\section{JURNAL BIDDJATI}

http://journal.uinsgd.ac.id/index.php/biodjati

bagi bahan pangan kebutuhan sehari-hari

(Gambar 6).

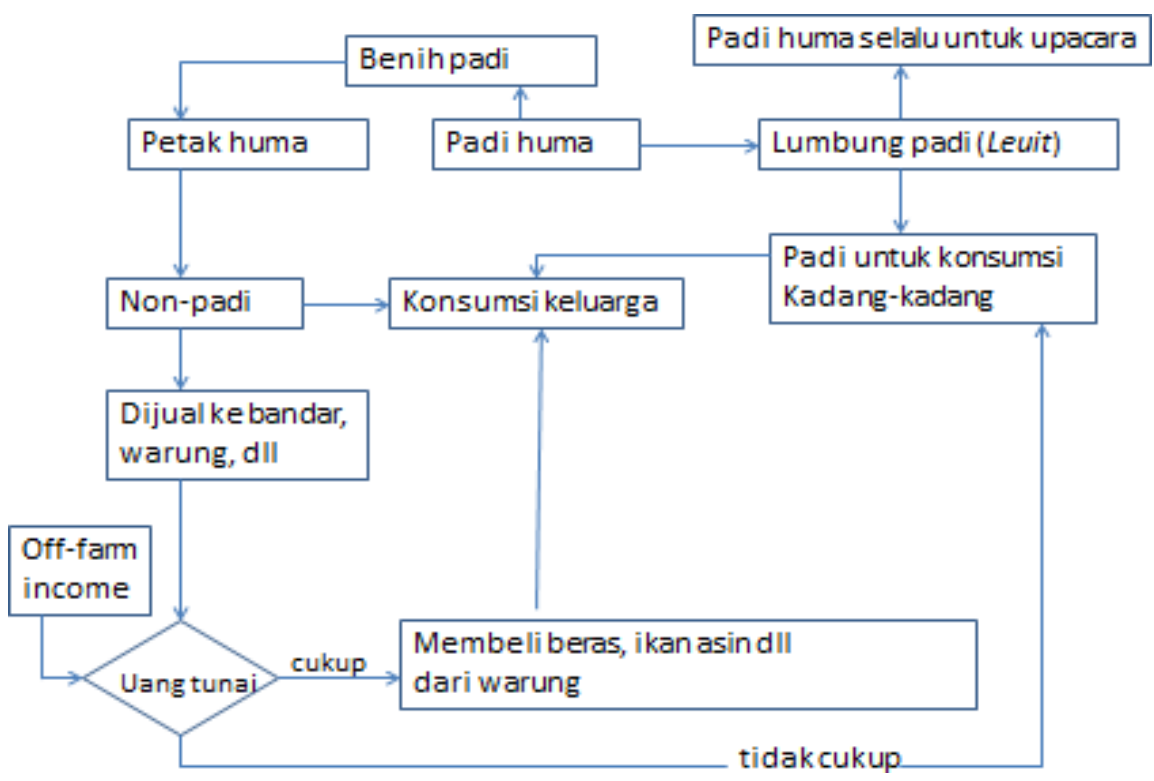

Gambar 6. Diagram pemanfaatan padi ladang (pare huma) oleh masyarakat Baduy, Banten Selatan (Iskandar, 2007; Iskandar et al., 2018).

Dampak dari program Revolusi Hijau menyebabkan kepunahan anekaragam varietas padi lokal di Indonesia. Usaha penyelamatan 10.000 varietas padi pernah di usahakan pemerintah di tahun 1980-an, tapi upaya itu gagal (Sastrapradja \& Widjaja 2010).

Selain itu, akibat program Revolusi Hijau terjadi kepunahan pengetahuan ekologi petani (Soleri \& Smith, 1999 ; Hardiyoko \& Saryoto, 2005 ; Winarto, 2011). Padahal sebelum program tersebut bergulir, para petani memiliki pengetahuan ekologi lokal yang sangat kaya seperti pengetahuan mengenai tata-cara bertani dengan mengadaptasikan pada dinamika perubahan lingungan dengan cara menyusun pranata mangsa, pengetahuan menyeleksi benih padi, membuat pupuk organik, dan cara mengatasi hama dengan pestisida alami dan lain-lain (Iskandar \& Iskandar, 2016) . Sementara itu, dengan adanya program Revolusi Hijau para petani dikondisikan sekedar menjadi pembeli dan penanam benih pemerintah (Prahara, 2011).

Penelitian ini memiliki kontribusi penting untuk ilmu pengetahuan dan kepentingan praktis, seperti bermanfaat untuk pengembangan ilmu pengetahuan khususnya dalam bidang etnoekologi dan etnobotani, serta diharapkan hasil penelitian ini dapat digunakan bagi berbagai pihak terkait untuk masukan guna upaya konservasi anekaragam padi di Indonesia

Berdasarkan studi etnoekologi tanaman padi dari studi kasus pada masyarakat Baduy, Banten dan masyarakat Kampung Naga, Tasikmalaya, dapat disimpulkan bahwa para petani huma Baduy dan petani sawah penduduk Naga memiliki peran penting mengkonservasi anekaragam varietas padi lokal secara in-situ. Dengan kata lain, bahwa upaya konservasi anekaragam genetik tanaman padi bukan saja dilakukan oleh pemerintah, tapi juga dapat dilakukan oleh para petani secara turun temurun. Kebiasaan para petani 


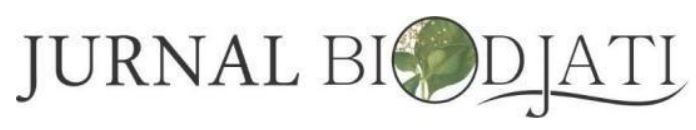

http://journal.uinsgd.ac.id/index.php/biodjati

untuk memilih anekaragam varietas padi sesuai dengan pertimbangannya, seperti soal cita rasa atau kuliner, kesuaian lokasi tempat tanaman, musim, kondisi sistem ketersediaan air, dan umur panen padi. Maka, dengan berbagai pilihan para petani tersebut, telah menyebabkan terbentuknya anekaragam varietas padi lokal pada sistem pertanian petani. Namun, akibat kebijakan permerintah yang memodernkan usaha tani sawah yang sangat menekankan hanya pada asek produksi, dengan mengintroduksikan beberapa varietas padi baru, melalui program Revolusi Hijau. Akibatnya, berbagai varietas padi lokal mengalami kepunahan secara massal. Maka, kepunahan keanekaragam varietas padi dapat disebabkan oleh kebijakan pemerintah, perubahan ekosistem dan akibat berubahnya sistem sosial ekonomi dan budaya masyarakat. Dalam upaya konservasi anekaragam varitas padi lokal di Indonesia seyogianya dapat melibatkan partisipatif aktif penduduk perdesaan. Selain itu, pengetahuan ekologi lokal peduduk pedesaan seyogianya dapat dipadukan dengan pengetahuan ilmiah Barat, guna mendukung pembangunan pertanian berkelanjutan di Indonsia.

\section{DAFTAR PUSTAKA}

Alburquerque U.P, Cruz da Cunha L.V.F, Lucena R.F.P. \& Alves R.R.N (eds). (2014). Methods and techniques in Ethnobiology and Ethnoecology. New York: Springer Science \& Business Media.

Beets.W.C. (1990). Raising and Sustaining Productivity of Smallholders Farming Systems of Smallholders Farmings in the Tropics. Alkmaar: AgBe Publishing.

Berkes, F. (1999). Sacred Ecology: Traditional Ecological Knowledge and Resource
Management. Philadelphia:Taylor Francis.

Berlin, B., Breedlove, D. E. \& Raven, P. H. (1973). General Principles of Calssification and Nomenclature in folk biology. American Anthropology Vol.75, Hal 214-242.

Bernsten, R.J., Siwi, B. H. \& Beachell, H.M. 1982. The Development and diffusion of rice varieties in Indonesia. Los Banos: IRRI.

Brown, C.H. (2000). Folk Classification: Introduction. Dalam P.E. Minnis (ed), Ethnobotany: A

Reader. University of Oklahoma Press:

Norman.hal.65-68.

Brush, S. B. (1992). . Ethnoecology, Biodiversity, and Modernization in Andean Potato Agriculture. Journal of Ethnobiology. Vol 12 (2), Hal 161-185.

Budi, S. (1997). Variasi Jenis Padi Kasepuhan. Skripsi Antropologi, Universitas Padjadjaran.

Burkill, I.H. 1935. A Dictionary of the Economic Product of the Malay Peninsula. London: Crown Agents for the Colonies.

Damus, D. (1992). Inventarisasi Varietas Padi di Desa Long Alango dan Desa Apau Ping, Kecamatan Pujungan, Kalimantan Timur. Laporan Penelitian Proyek Kayan Mentarang, Kantor WWF, Samarinda.

Damus, D. (1993). Inventarisasi Varietas Padi di Desa Binuang dan Desa Ba'Liku, Kecamatan Krayan, Kalimantan Timur. Laporan Penelitian Proyek Kayan Mentarang. Kalimantan.

Darpan, Abdurachman, Soepandai, A., Mauanas, D. \& Rusyana, Y. (2013). Kompedium Sistem Pertanian Tradisional Sunda. Bandung: Dunia Pustaka Jaya.

Dove, M.R. (1988). Sistem Perladangan di Indonesia: Suatu Studi-Kasus dari Kali- 


\section{JURNAL BIODJATI}

http://journal.uinsgd.ac.id/index.php/biodjati

mantan Barat. Yogyakarta: Gadjaha Mada University Press.

Ellen, R. F \& H. Harris. (2000). Introduction. Dalam R.F. Ellen, P. Parkes, A.Bicker (eds), Indigenous Environmental Knowledge and its Transformation: Critical Anthrophological Perspective. Mterdam: Hardwood Academic Publishers.

Fox, J. J. (1991). Managing the Ecology Of Rice Production in Indonesia. In $\mathrm{J}$ Hardjono (ed), Indonesia: Resources, ecology and environment. Singafore: Oxfod University Press, hal.61-64.

Fox, J. J. (1993). The Rice Basket of East Java: The Ecology and Social Contex of Sawah Production. In Dick H, J.J Fox and Mackie, J (eds), Balance Development: East Java in New Order. Singafore: Oxford University Press, hal.120-157.

Fox, J. J. (1997). Lumbung Beras di Jawa Timur: Ekologi dan Konteks Sosial Produksi Sawah. Dalam Dick H, Fox, J.J. dan Mackie, J. (eds), Pembangungan yang berimbang; JawaTimur dalam Era Orde Baru. Jakarta: Penerbit PT Gramedia Pusataka Utama, hal.167-2018.

Hardiyoko \& Saryoto, P. (2005). Kearifan Lokal dan Stok Pangan Desa. Dalam Wahono F, Widyanta A.B, Kusumajati, T.O (eds), Pangan Kearifan Lokal \& Keanekaragaman Hayati Pertaruhan Bangsa yang terlupakan. Yogkarata: Cinderalas Puataka Rakyat Cerdas, hal. 197-213.

Igarashi, T. (1985). Some notes on the subsistence in a Sundanese village. In Suzuki S, O Soemarwoto, T Igarashi (eds), Human Ecology Survey in Rural West Java in 1978 to 1982. Tokyo: Nissan Science Foundation, hal.9-77.

Iskandar, J. (1998). Swidden Cultivation as a Form of Cultural Identity: The Baduy
Case. Disertasi. University of Kent at Canterbury. (Tidak dipublikasikan).

Iskandar, J. (2001). Manusia Budaya dan Lingkungan: Kajian Ekologi Manusia. Bandung: Utama Press, Bandung.

Iskandar, J. (2007). Responses to Environmental Stress in the Baduy Swidden System, South Banten, Java. In Ellen, R. (ed), Modern Crises and Traditional Strategies: Local Ecological Knowledge in Island Southeast Asia. New York: Berghahn Books, hal.112-132.

Iskandar J. (2012). Etnoekologi dan Pembangunan Berkelanjutan. Bandung: Pusat Pengkajian Kebijakan Publik, LPPM, UNPAD.

Iskandar J. (2017). Ekologi Manusia dan Pembangunan Berkelanjutan. Bandung: Program Magister Ilmu Lingkungan, Unpad, Edisi Revisi.

Iskandar, J. (2017). Local knowledge of the Baduy Community of South Banten (Indonesia) on the traditional landscapes. Biodiversitas, Journal of Biological Diversity, 18(3), 928-938. https://doi.org/10.13057/biodiv/d180309

Iskandar, J. \& Ellen. (1999). In Situ Conservation Of Rice Landraces Among The Baduy Of West Java, Journal of Ethnobiology. Vol 19 (1), Hal 97-125.

Iskandar, J. \& Iskandar, B. S. (2011). Agroekosistem Urang Sunda. Bandung: Kiblat Buku Utama.

Iskandar, J., Iskandar, B. S. (2016). Etnoekologi dan pengelolaan Agroekosistem oleh Penduduk Desa Karangwangi Kecamatan Cidaun Cianjur Selatan, Jawa Bar at. Jurnal Biodjati, 1 (1), $1-12$.

Iskandar, J. \& Iskandar, B. S. (2017a). Local Knowledge of Baduy Community of South Banten (Indonesia) on the Tradi- 


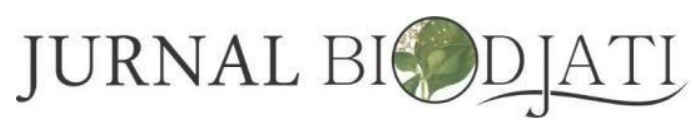

http://journal.uinsgd.ac.id/index.php/biodjati

tional Landscapes. Biodiversitas, 18 (3), , 928-938. .

Iskandar, J. \& Iskandar, B. S. (2017b). Kearifan Ekologi Orang Baduy Dalam Konservasi Padi Dengan " Sistem Leuit ," Jurnal Biodjati, 2(1), 38-51.

Iskandar, J. \& Iskandar, B.S. (2017c.) Various Plants of Traditional Rituals:

Ethnobotanical Research Among Baduy Community. Biosaintifica, 9 (1), 114-125. Iskandar, J, Iskandar B.S. \& Partasasmita, R. (2018). Strategy of Outer Baduy commu- nity of South Banten (Indonesia) to sustain their swidden farming traditions by tem- porary migration to non-Baduy areas. Biodiversitas. 19 (2), 453-464.

Jamthani, H. (2008). Lumbung Pangan: Menata Ulang Kebijakan Pangan. Yogyakarta: INSISTPress.

Mustapa, H. (1996). Adat Istiadat Sunda. Bandung: Penerbit Alumni.

Kools, J. F. (1935). Hoema's hoemablocken en Boschreserven in de Residente Banten. Wageningen: Proefschrift H.Veenman \&Zonen.

Newing, H., Eagle C.M, Puri R. K. \& Watson

C.W. (2011). Conducting research in conservation: a social science perspective. London dan New York: Routledge.

Parkesit, Djuniwarti \& Hadikusumah, H.Y. (1997). Spatial Structure And Floristic Diversity Of Man-Made Ecosystem In Upper Citarum River Basin. In Dove, M.R and Sajise, P. (eds), The conditions of biodiversity maintenance in Asia. Hawaii: East-Center, hal. 17-43.

Permana, S., Iskandar, J. \& Parikesit. (2017). Local Knowedge On Rice Variations (Landraces) Of The Naga Community, West Java, Indonesia. Journal of Indonesia Ethnobiology Vol.1.

Prahara, H. (2011). Menonton Film Bisa Dewek: Perubahan Pengetahuan dan
Parktik Pada Kelompok Tani Sri Cendana. Dalam Winarto, Y.T (ed), Bisa Dewek: Kisah Perjuangan Petani Pemulia di Indramayu.Jakarta: Gramata Publishing, hal.69-100.

Sastapradja, S. D \& Widjaja, E. A. (2010). Keanekaragaman Hayati Pertanian Menjamin Kedaulatan Pangan. Jakarta: LIPI Press.

Setyawati, I. (1999). Pengetahuan Tentang Varietas-Varietas Padi dan Pemanfaatannya di Kalangan Orang Kenyah Leppo'ke di Apau Ping. Dalam Eghenter, C. \& Sellato, B (eds), Kebudayaan dan Pelestarian Alam: Penelitian Interdisipliner di Pedalaman Kalimantan. Jakarta: WWF Indonesia, hal 97-113.

Shiva, V. (1991). The Violence of Green Revolution: Third World Agriculture, Ecology and Politics. London: Zed Books dan Penang: Third World Network.

Shiva, V. (1993). Monoculture of The Mind: Perspective on Biodiversity and Biotechnology. London: Zed Books dan Penang: Third World Net Work.

Soemardjan, S. \& Brazeale, K. (1993).Cultural Change in Rural Indonesia: Impact of village Development. Surakarta: Sebelas University Press.

Soemartono. (2005). Upaya Penyelamatan Varietas Padi Lokal Dengan Pemuliaan Tanaman Serta Teknologi Konseravasi dan Penyimpanannya. Dalam Wahono F,Widyanta A.B, Kusumajati, T.O (eds), Pangan Kearifan Lokal \& Keanekaragaman Hayati Pertaruhan Bangsa yang terlupakan. Yogyakarta: Cinderalas Puataka Rakyat Cerdas, hal. 181-195.

Soemarwoto, R. (2007). Kasepuhan Rice Landrace Diversity, Risk Management and Agricultural Modernization. In Ellen, 


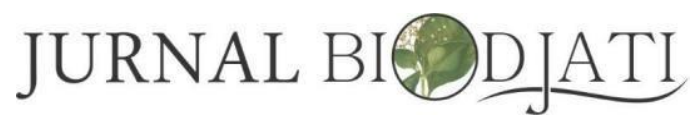

http://journal.uinsgd.ac.id/index.php/biodjati

R. (ed), Modern Crises and Traditional Strategies: Local Ecological Knowledge in Island Souteast Asia. New YorkOxford: Berghn Book, hal.84-111.

Soleri, D. \& Smith, S.E. (1999). Conserving Folk Varieties: Different Agricultures, Different Goals. In Nasarea (ed), Ethnoecology: Situated

Knowledge/Located Lives. Tuscon: The University of Arizona Press. hal.133-154.

Sudarwandi, M. M. (2016). A Study on House Pattern of Kampung Naga in Tasikmalaya, Indonesia. International Journal of Technology Enhancements and Emerging Enginering Research, 4 (58), 2347-4289.

Suganda, H. (2006). Kampung Naga Mempertahankan Tradisi. Bandung: PT Kiblat Buku Utama.

Toledo, V. M. (2002). Ethnoecology: A Conceptual Framework for the Study of Indiginous Knowledge of Nature. Dalam J.R. Stepp, F.S. Wyndham, and R.K. Zarger (eds), Ethnobiology and Biocultural. The International Society of Ethnobiology, Georgia.

Warsiti, I. (2009). Pengelolaan dan Pemanfaatan Padi Lokal dan FaktorFaktor yang mempengaruhi Kelestarian Kultivar Padi Lokal. Tesis pada Program Studi Magister Ilmu Lingkungan, Universitas Padjadajaran (Tidak Diterbitkan).
Whitten, T. R.E. Soeriatmadja, S. A. \& Afiff. (1999). Ekologi Jawad an Bali. Jakarta: Prenhallindo.

Widjaja EA dan Jessup TC 1986.Short Description of Indigenous Rice from East Kalimantan, Indonesia.FAO/IBPGR. Plant Genetic Resources Newsletter, Food Agriculture Organization, Rome, 67, Hal 44-45.

Warren, D.M., Slikkerveer, L.J. \& Brokensha, D. (eds). (1995). The Cultural Dimensions of Develoment: Indigenous Knowledge Systems.London: Intemediate Technology Publications.

Widjaja, E. A., Rhayuningsih, Y., Rahajoe, J. S., Ubaidillah, R, Maryanto, I, Waluyo, E. B \& G Semiadi, G. (2014). Kekinian Keanekaragaman Hayati Indonesia 2014. Jakarta: LIPI Press.

Winarto, Y. T. (2011). Kembalinya Benih dan Pengetahuan Lokal Dalam Budi Daya Padi. Dalam Winarto YT (ed), Bisa Dewek: Kisah Perjuangan Petani Pemulia Tanaman di Indramayu. Jakarta: Gramata Publishing, hal. 201-229. 